\title{
PENYUSUNAN LAPORAN \\ HASIL PENELITIAN TINDAKAN KELAS
}

\author{
Slameto \\ slameto_usw@yahoo.com \\ Pendidikan Guru Sekolah Dasar \& PPS-MP - FKIP - UKSW Salatiga
}

\begin{abstract}
ABSTRAK
Tujuan menulis laporan secara sederhana adalah untuk mencatat, memberitahukan, dan merekomendasikan hasil penelitian. Oleh karena itu laporan PTK ditulis karena merupakan dokumen yang dapat dijadikan acuan, serta dapat diketahui oleh umum, terutama oleh para guru yang barangkali mengalami masalah yang sama dengan yang dilaporkan. Sistematika laporan hasil terdiri dari 3 bagian yaitu: awal, pokok, dan akhir. Bagian awal terdiri dari: halaman judul, kata pengantar, abstrak, daftar isi, daftar tabel, daftar gambar dan daftar lampiran. Uraian berikut ini menjelaskan teknik penulisannya. Bagian Pokok Laporan terdiri dari 5 bab, yaitu Bab I Pendahuluan, Bab II Kajian Pustaka, Bab III Metode Penelitian Tindakan Kelas, Bab IV Pelaksanaan dan Hasil Penelitian Tindakan Kelas serta Pembahasan, Bab V Penutup. Bagian akhir dari format laporan penelitian terdiri dari daftar pustaka dan lampiranlampiran.
\end{abstract}

Kata kunci: laporan PTK, Pendahuluan, Kajian Pustaka, Metode Penelitian, Hasil Penelitian

\section{PENGANTAR}

Laporan PTK merupakan pernyataan formal tentang hasil penelitian, atau hal apa saja yang memerlukan informasi yang pasti, yang dibuat oleh seseorang atau badan yang diperintahkan atau diharuskan untuk melakukan hal itu. Ada beberapa jenis laporan misalnya Rapor Sekolah, Laporan Hasil Praktikum, dan Hasil Tes Laboratorium. Sedangkan laporan PTK termasuk jenis laporan lebih tinggi penyajiannya.

Laporan hasil PTK adalah laporan yang ditulis secara sistematis berdasarkan penelitian tindakan kelas yang dilakukan oleh guru di kelasnya sendiri. Tujuan menulis laporan secara sederhana adalah untuk mencatat, memberitahukan, dan merekomendasikan hasil penelitian. Maka dari itu laporan PTK ditulis karena merupakan dokumen yang dapat dijadikan acuan, serta dapat diketahui oleh umum, terutama oleh para guru yang barangkali mengalami masalah yang sama dengan yang dilaporkan. 
Sistematika laporan hasil PTK pada umumnya tidak jauh berbeda dari laporan penelitian formal. Laporan hasil PTK terdiri dari 3 bagian yaitu: awal, pokok, dan akhir. Selanjutnya tulisan ini memaparkan 3 bagian tersebut.

\section{BAGIAN AWAL}

Bagian awal Laporan Penelitian Hasil PTK terdiri dari: halaman judul, kata pengantar, abstrak, daftar isi, daftar tabel, daftar gambar dan daftar lampiran. Uraian berikut ini menjelaskan teknik penulisannya. Namun sebelum masuk ke masingmasing item bagian awal laporan, disajikan terlebih dahulu tentang sampul/cover laporan hasil PTK (Budi Herijanto, 2011).

\section{Sampul}

Padabagian tengah atas terdapat logo lembaga pendidikan dimana penulis bekerja bergaris tengah tidak lebih dari $6 \mathrm{~cm}$; Di bawahnya dituliskan judul dengan huruf capital tebal berukuran 15-16. Di bawahnya tertulis kata Laporan Penelitian Tindakan Kelas yang dicetak dengan huruf capital tebal berukuran lebih kecil (14). Di bawahnya dituliskan dengan huruf berukuran 12 kata Oleh (tanpa tanda titik dua), dibawahnya lagi dituliskan nama, dan di bawahnya lagi NIP/NIS (diisi angkanya). Pada kaki halaman dituliskan dengan huruf kapital tebal berukuran lebih kecil daripada judul (14-15) nama lembaga pendidikan dimana penulis bekerja, dan di bawahnya lagi ditulis tahun berapa laporan tersebut disusun. Semuanya itu dicetak dengan huruf misalnya time new romantegak, diatur secara simetris dengan komposisi yang serasi. Sampul dibuat dari bahan tebal. Di punggung sampul dibubuhkan logo (berdiri), nama (memanjang, dengan huruf biasa berukuran 12), judul (memanjang, dengan huruf kapital berukuran 14), Laporan Hasil PTK dan tahun (Budi Herijanto, 2011).

\section{Halaman Judul}

Lembar judul bunyinya sama dengan yang terdapat pada sampul, hanya saja dicetak pada kertas HVS putih dengan bobot terendah 70 gram.

Halaman Moto dan Persembahan

Motto dan Persembahan boleh ada, boleh tidak. Motto disini adalah ungkapan bijak untuk kehidupan, yang dipilih berkaitan dengan judul penelitian. Persembahan adalah pernyataan, karya ilmiah itu dipersembahkan kepada siapa, yaitu lembaga atau organisasi profesi yang perlu menindak-lanjuti PTK.

\section{Abstrak}

Abstrak ditulis pada lembar baru, berjudul ABSTRAK, ditulis di tengah atas, dicetak dengan huruf kapital. Di bawahnya, dengan jarak dua spasi dicantumkan nama akhir penulis, diikuti tanda koma, lalu nama depan dan tengah 
(kalau ada), diikuti tanda titik, lalu tahun ..., diikuti tanda titik; diikuti judul penelitian. Selanjutnya dicantumkan kata "Program dan lembaga penulis bekerja diakhiri tanda titik, disusul dengan pencantuman nama pembimbing (jika ada).

Pada baris berikutnya, dengan jarak dua spasi ditulis teks abstrak dengan spasi satu. Isi abstrak meliputi latar belakang masalah, rumusan atau fokus masalah, metode yang digunakan, hasil yang diperoleh, dan saran yang diajukan. Butir-butir itu hendaklah ditulis dalam paragraf yang berbeda, dengan tidak menolak kemungkinan untuk memecah butir tertentu untuk dituangkan dalam paragraf yang berbeda kalau diperlukan. Pada baris baru berikutnya dicantumkan kata kunci: ..., berkisar dari tiga sampai dengan lima kata.Teks abstrak tidak boleh lebih dari satu halaman kuarto (Budi Herijanto, 2011).

\section{Prakata}

Lembar Kata Pengantar berjudul Prakata yang diletakkan di tengah atas. Dalam Prakata boleh dikemukakan ungkapan puji syukur dan terima kasih, namun yang pokok adalah pengantar yang di ikuti ucapan terima kasih dan penghargaan kepada orang-orang, lembaga, atau lainnya yang langsung membantu pelaksanaan penelitian dan penulisan laporan. Dalam Prakata tidak boleh ada pernyataan bahwa penulis yakin akan adanya banyak kesalahan atau kekurangan dalam penelitiannya dan atas dasar itu penulis minta maaf, serta mengharapkan kritik dari pembaca. Kalau penulis yakin bahwa dalam penelitian dan laporannya itu masih banyak kesalahan atau kekurangan, penelitian dan atau laporannya itu harus diperbaiki terlebih dahulu, baru dilaporkan atau dipublikasikannya karena kesalahan ilmiah tidak dapat diselesaikan dengan permintaan maaf. Lagi pula harapan kritik itu tidak diperlukan sebab laporan penelitian adalah karya ilmiah untuk dipublikasi, bukankah sebelumnya sudah direview?. Kalau naskah itu baru akan diterbitkan, permintaan kritik itu dinyatakan. Teks Prakata diketik dengan spasi satu setengah, seperti halnya naskah bagian utama, tidak boleh lebih dari satu halaman. Pada akhir teks Prakata dicantumkan kata Penulis, tanpa disertai nama, diletakkan di pojok kanan bawah (Budi Herijanto, 2011).

\section{Daftar isi}

Dalam daftar isi dimuat judul-judul yang terdapat pada bagian awal laporan penelitian, mulai dari abstrak, judul bab beserta sub-bab dan anak sub-babnya masing-masing, dan judul-judul pada bagian akhir. Kecuali judul sub-bab dan anak sub-bab, semuanya diketik dengan huruf kapital. Judul-judul itu diikuti titik-titik sepanjang baris, diikuti nomor halaman tempat judul itu terdapat pada halaman lembar laporan penelitian. 


\section{Daftar Tabel, Gambar dan Lampiran}

Jika dalam bagian pokok terdapat tabel dan atau gambar lebih dari 4, perlu ada daftar tabel dan daftar gambar; demikian juga jika dalam lampiran lebih dari 4, perlu dibuat daftar lampiran. Tetapi jika kurang dari 5 tabel atau kurang dari 5 gambar, atau kurang dari 5 lampiran, maka tidak perlu dibuat daftarnya. Daftar tabel memuat nomor dan judul tabel, diikuti titik-titik seperti pada daftar isi, lalu disusul nomor halaman tempat tabel terdapat dalam teks. Judul tabel yang lebih dari satu halaman ditik dengan spasi satu. Jarak antara judul yang satu dengan yang lain dalam daftar itu satu setengah spasi. Cara membuat gambar sama dengan cara membuat daftar tabel. Cara membuat daftar lampiran sama juga dengan cara membuat daftar tabel.

\section{BAGIAN POKOK}

Bagian Pokok Laporan Penelitian terdiri dari 5 bab, yaitu Bab I Pendahuluan, Bab II Kajian Pustaka, Bab III Metode Penelitian Tindakan Kelas, Bab IV Pelaksanaan dan Hasil Penelitian Tindakan Kelas serta Pembahasan, Bab V Penutup. Revisilah proposal menjadi Bab I, Bab II dan Bab III laporan penelitian. Kemudian lakukan tindakan sekaligus pengumpulan data untuk menyusun Bab IV dan Bab V.

\section{BAB I: PENDAHULUAN}

Bagian ini adalah bab pertama laporan penelitian yang mengantarkan pembaca untuk mengetahui ikhwal topik penelitian, alasan dan pentingnya penelitian. Oleh karena itu, bab pendahuluan memuat uraian tentang (1) latar belakang masalah penelitian, (2) identifikasi masalah (3) rumusan masalah, (4) tujuan penelitian, dan (5) kegunaan/manfaat penelitian. Berdasarkan hasil review proposal beserta masukan dari berbagai fihak, lakukan revisi proposal menjadi bab 1 Pendahuluan (Budi Herijanto, 2011).

\section{Latar Belakang Masalah}

Dalam latar belakang permasalahan uraikan lebih rinci lagi urgensi penanganan permasalahan yang diajukan melalui PTK. Untuk itu, harus lengkapi lagi dengan data atau fakta-fakta yang mendukung, baik yang berasal dari pengamatan saudara yang juga guru selama ini maupun dari kajian pustaka terkini yang lebih banyak lagi. Usahakan adanya dukungan hasil-hasil penelitian terdahulu yang lebih banyak sehingga lebih mengokohkan argumentasi mengenai urgensi serta signifikansi permasalahan yang ditangani melalui PTK (Budi Herijanto, 2011). 


\section{Identifikasi masalah}

Berdasarkan kelengkapan data yang dipaparkan pada latar belakang hendaknya kesenjangan antara kenyataan (kondisi awal) dan harapan (kondisi akhir) menjadi lebih tajam; sehingga masalah penelitian benar-benar di angkat dari masalah keseharian di sekolah yang memang layak dan perlu diselesaikan melalui PTK (Budi Herijanto, 2011). Uraian permasalahan hendaknya didahului oleh identifikasi masalah, yang dilanjutkan dengan analisis masalah serta diikuti dengan refleksi awal sehingga gambaran permasalahan yang perlu di tangani itu nampak menjadi lebih spesifik (pembatasan masalah tersebut). Dalam bagian inipun, sosok PTK secara konsisten tertampilkan (Muhammad Daffa, 2008).

\section{Rumusan masalah}

Rumusan masalah dikembangkan dari identifikasi dan pembatasan masalah; Umumnya berbentuk kalimat tanya. Kalimat tanya pada rumusan masalah lebih terinci karena telah melalui identifikasi dan pembatasan masalah. Kalimat tanya yang diajukan mengacu ke variabel pada masalah pokok (Y) dan variabel pada masalah lain yang diteliti (X). Rumusan masalah disusun sesuai substansi bentuk rumusan PTK; disamping adanya permasalahan yang akan diatasi, ada alternatif tindakan yang akan diambil dan hasil positif yang diantisipasi. Rumusan masalah sebaiknya 2 atau lebih (Budi Herijanto, 2011).

\section{Tujuan penelitian}

Tujuan penelitian mengungkapkan apa yang hendak dicapai dengan penelitian. Rumusannya sejajar dengan rumusan masalah. Dirumuskan secara singkat dan jelas tentang apa yang ingin diatasi atau dicapai berdasarkan permasalahan dan cara pemecahan masalah yang dikemukakan.

\section{Kegunaan penelitian}

Kegunaan/manfaat diuraikan secara jelas dan sistematis baik; Kemukakan manfaat bagi peserta didik, guru, komponen pendidikan terkait di sekolah, baik bagi pengembangan ilmu maupun bagi kepentingan praktek. Adanya uraian ini dimaksudkan untuk menunjukkan bahwa masalah yang dipilih memang layak diteliti.

\section{BAB II KAJIAN PUSTAKA}

Pada bagian ini materi dari proposal diperluas dan dipertajam lagi sehingga kajian penelitian yang relevan, teori, kerangka berpikir dan hipotesis tindakan menjadi lebih sempurna. Uraikan dengan lebih jelas lagi kajian pustaka dan teori yang benar-benar mendasari rancangan penelitian tindakan. Tunjukkan adanya 
dukungan temuan dan bahan penelitian lain terhadap pilihan tindakan untuk mengatasi permasalahan penelitian saudara. Dengan begitu kerangka berpikir atau kerangka konsep yang saudara gunakan dalam penelitian makin kokoh. Demikian juga hipotesis tindakan yang menggambarkan indikator keberhasilan tindakan yang saudara harapkan/diantisipasi.

\section{Kajian Teori}

Dalam kerangka teoriris dinyatakan teori apa yang digunakan untuk landasan kerja penelitian. Teori itu bisa disusun sendiri secara elektik, bisa juga berupa teori yang digunakan oleh seorang ahli. Namun, teori apapun yang digunakan harus dipertanggung-jawabkan melalui kajian sejumlah pustaka yang juga memuat hasil penelitian dalam lingkup topik penelitian yang menggunakan teori terpilih ataupun yang menggunakan teori yang berbeda. Teori itu dikaji secara kronologis, dari yang lama sampai dengan yang mutakhir untuk menunjukkan kemajuan hasil penelitian sejalan dengan perkembangan teori. Dengan cara itu, diantara sederet teori, keunggulan teori yang dipilih sebagai landasan kerja penelitian menjadi tampak (Budi Herijanto, 2011).

Penyebutan nama teori saja tidaklah cukup. Prinsip-prinsip teori itu perlu diuraikan, termasuk pendekatan dan metode kerja teori itu. Variabel-variabel pembangun topik penelitian juga perlu diterangkan menurut pandangan teori yang dipilih itu. Untuk itu landasan teori merupakan pemaparan konsep-konsep berdasar pada pendapat orang lain kemudian dilakukan kajian, pada akhirnya dipaparkan menurut sudut pandang penulis dengan disertai cara mengukurnya.

Dukungan dasar teoritis dalam rangka memberi jawaban terhadap pendekatan pemecahan masalah diartikan sebagai menyusun kerangka teoritis berfungsi sebagai dasar penyusun hipotesis penelitian. Dengan uraian tentang teori itu hakikat topik penelitian menjadi jelas. Variabel-variabel, masalah, dan tujuannya tergambarkan secara operasional. Data pun dapat teridentifikasi, sedangkan lahan pengambilan data dapat ditentukan. Dengan demikian, teknik pengumpulan, pengolahan, dan analisis data dapat dirancang. Jadi, kerangka teoritis tidak hanya melandasi identifikasi sasaran, tetapi juga melandasi metode penelitian (Budi Herijanto, 2011).

Berdasarkan pemikiran seperti di atas, maka lengkapilah kajian teori yang saudara paparkan (pada proposal) sebagai landasan substantive teoritik dan/atau metodologik dengan referensi terkini baik yang berbahasa Indonesia maupun bahasa Inggris dari jurnal dan hasil penelitian yang relevan. Tinjauan teori yang berisi falsafah dasar, teori, dan konsep menjadi sangat kokoh dan menunjukkan erat kaitannya dengan fokus masalah penelitian yang saudara lakukan. Deskripsikan kajian teori yang memang relevan dengan topik penelitian yang dilakukan, terutama variabel yang saudara atasi dan variabel yang saudara gunakan untuk mengatasinya, 
tonjolkan peran saudara dalam mengembangkan teori sesuai manfaat teoritis yang saudara paparkan (Budi Herijanto, 2011).

\section{Kajian Hasil-Hasil Penelitian yang Relevan}

Lengkapilah referensi hasil penelitian yang berasal dari jurnal dan atau laporan penelitian yang relevan dengan permasalahan dan variabel yang saudara teliti. Kajian ini menjadi dasar ulasan hasil penelitian saudara kelak. Tonjolkan peran saudara dalam mengembangkan teori sesuai manfaat teoritis yang akan saudara cari datanya. Argumentasi logis dan teoretik diperlukan bukan hanya untuk membuat ulasan, tetapi juga untuk menyusun kerangka teori/konseptual (yang sesuai teori yang baru saja saudara - akan kembangkan) (Budi Herijanto, 2011).

\section{Kerangka Pikir}

Buat kerangka pemikiran yang menjelaskan keandalan tindakan untuk mengatasi masalah. Pertajamlah naskah dalam proposal saudara sehingga peubah/ variabel dicantumkan sebatas yang diteliti dan dapat dikutip lebih dari tiga karya tulis/bacaan sebelumnya. Tekankan bahwa kerangka teori yang saudara paparkan memang menggunakan acuan yang berhubungan dengan permasalahan yang saudara teliti dan pustaka-acuan yang berupa hasil penelitian terdahulu (3 tahun terakhir). Semakin banyak sumber bacaan/acuan, semakin baik. Susun model teori yang merupakan kerangka pemikiran saudara dalam penelitian yang sedang dilakukan. Dari kerangka teori dalam sebuah skema, jabarkan hal-hal yang perlu untuk memberikan batasan-batasan, beserta asumsi-asumsinya (Budi Herijanto, 2011).

\section{Hipotesis Tindakan/Penelitian}

Tinjau kembali hipotesis yang saudara turunkan dari kerangka pemikiran. Berdasarkan rumusan masalah penelitian, tinjauan pustaka, dan kerangka pemikiran, maka rumuskan ulang hipotesis saudara. Dengan demikian jawaban sementara yang saudara rumuskan berdasarkan kajian teori dan pustaka serta kerangka berpikir semakin kokoh menjawab rumusan masalah yang diajukan.

\section{BAB III METODE PENELITIAN}

Dalam metode penelitian ini dipaparkan: setting penelitian dan karakteristik subjek penelitian, variabel yang diselidiki, rencana tindakan, data dan cara pengumpulannya, indikator kinerja dan analisis data.

\section{Setting dan Karakteristik Subjek Penelitian}

Tegaskan pada bagian ini tentang setting dan subyek penelitian yang saudara pilih/tetapkan. Uraikan lebih rinci subyek penelitian saudara, serta 
karakteristik subjek di mana penelitian saudara lakukan; demikian juga aspek substantive permasalahan.

\section{Variabel yang Diselidiki}

Sebut dan rumuskan variabel yang diselidiki secara operasional berdasarkan definisi teoritis yang saudara rumuskan pada Bab II baik (1) variabel X atau tindakan yaitu proses penyelenggaraan KBM yang inovatif seperti interaksi belajarmengajar, keterampilan bertanya, gaya mengajar guru, cara belajar peserta didik, implementasi berbagai metode mengajar di kelas, dan sebagainya (2), varaibel $\mathrm{Y}$ atau output seperti rasa keingintahuan peserta didik, kemampuan peserta didik mengaplikasikan pengetahuan, motivasi peserta didik, hasil belajar peserta didik, sikap terhadap pengalaman belajar yang telah digelar melalui tindakan perbaikan. Selain itu tetapkan indikator dari masing-masing variabel yang saudara teliti (Budi Herijanto, 2011).

\section{Prosedur Penelitian}

Prosedur Penelitian mencakup: perencanaan tindakan, pelaksanaan tindakan dan observasi serta analisis dan refleksi serta evaluasi. Revisi dan pertajam rancangan penelitian pada proposal dengan mendeskripsikan persiapan tindakan saudara; kegiatannya mencakup: penyusunan rencana tindakan (skenario pembelajaran/RP), penyusunan media, penyusunan materi, penyusunan instrumen, simulasi rencana tindakan (skenario pembelajaran/RP). Deskripsikan secara rinci rencana pelaksanaan tindakan dalam bentuk RPP (Rencana Pelaksanaan Pembelajaran) serta jumlah pertemuaannya. Jelaskan secara lebih rinci data yang dikumpulkan dan teknik pengumpulan datanya (soal test, lembar observasi, kuesioner, dll.). Deskripsikan teknik analisis yang digunakan serta bahan dan prosedur refleksi yang digunakan. Dengan demikian pada bagian prosedur penelitian ini tergambarkan rencana tindakan untuk meningkatkan pembelajaran, implementasi tindakan beserta observasi dan interpretasi, analisis dan refleksi serta kriteria dan rencana perbaikan bagi tindakan daur berikutnya (Budi Herijanto, 2011).

\section{Data dan Cara Pengumpulannya}

Pada bagian data dan cara pengumpulannya ini ditunjukkan dengan jelas jenis data yang akan dikumpulkan yang berkenaan dengan baik proses maupun dampak tindakan perbaikan yang di gelar, yang digunakan sebagai dasar untuk menilai keberhasilan atau kekurang-berhasilan tindakan perbaikan pembelajaran yang dicobakan (Muhammad Daffa, 2008). Bagaimana pengembangan instrumen 
untuk mengukur keberhasilan tindakan. Format data dapat bersifat kualitatif, kuantitatif, atau kombinasi keduanya.

Instrumen yang diperlukan dalam PTK haruslah sejalan dengan prosedur dan langkah PTK. Instrumen untuk mengukur keberhasilan tindakan dapat dipahami dari dua sisi yaitu sisi proses dan sisi hal yang diamati. Dari sisi proses (bagan alirnya), instrumen dalam PTK harus dapat menjangkau masalah yang berkaitan dengan input (kondisi awal), proses (saat berlangsung), dan output (hasil) (Herawati Susilo dan Krisyani Laksono, 2008). Instrumen untuk input dapat dikembangkan dari hal-hal yang menjadi akar masalah beserta pendukungnya. Misalnya: akar masalah adalah bekal awal/ prestasi tertentu dari peserta didik yang dianggap kurang. Dalam hal ini tes bekal awal dapat menjadi instrumen yang tepat. Di samping itu, mungkin diperlukan pula instrumen pendukung yang mengarah pada pemberdayaan tindakan yang akan dilakukan, misalnya: format peta kelas dalam kondisi awal, buku teks dalam kondisi awal, dan seterusnya. Instrumen yang digunakan pada saat proses berlangsung berkaitan erat dengan tindakan yang dipilih untuk dilakukan. Dalam tahap ini banyak format yang dapat digunakan. Akan tetapi, format yang digunakan hendaknya yang sesuai dengan tindakan yang dipilih. Adapun instrumen untuk output berkaitan erat dengan evaluasi pencapaian hasil berdasarkan kriteria yang telah ditetapkan. Misalnya: 75\% siswa tuntas dengan KKM 60 ditetapkan sebagai ambang batas peningkatan (pada saat dilaksanakan tes bekal awal, jumlah peserta didik yang tuntas hanya 50\%), maka pencapaian hasil yang belum sampai pada $75 \%$ perlu untuk dilakukan tindakan lagi (pada siklus berikutnya) (Budi Herijanto, 2011).

Selain dari sisi proses (bagan alir), instrumen dapat pula dipahami dari sisi hal yang diamati. Dari sisi hal yang diamati, instrumen dapat dikelompokkan menjadi 3 (tiga), yaitu: instrumen untuk mengamati guru (observing teachers), instrumen untuk mengamati kelas (observing classroom), dan instrumen untuk mengamati perilaku peserta didik (observing students) (Herawati Susilo dan Krisyani Laksono, 2008).

Pengamatan terhadap perilaku peserta didik dapat mengungkapkan berbagai hal yang menarik. Masing-masing individu peserta didik dapat diamati secara individual atau berkelompok sebelum, saat berlangsung, dan sesudah usai pembelajaran. Perubahan pada setiap individu juga dapat diamati, dalam kurun waktu tertentu, mulai dari sebelum dilakukan tindakan, saat tindakan diimplementasikan, dan seusai tindakan. Adapun instrumen lain yang dapat digunakan dalam pengumpulan data PTK dapat berwujud: (1) pedoman pengamatan; (2) pedoman wawancara; (3) angket atau kuesioner; (4) pedoman pengkajian data dokumen dan (5) tes dan asesmen alternatif (Budi Herijanto, 2011). 
Guru yang berkolaborasi dapat berperan pula sebagai pewawancara terhadap peserta didiknya (Herawati Susilo dan Krisyani Laksono, 2008). Namun harus dapat menjaga agar hasil wawancara memiliki objektivitas yang tinggi. Indikator untuk angket atau kuesioner dikembangkan dari permasalahan yang ingin digali. Dokumen yang dikaji dapat berupa: daftar hadir, silabus, hasil karya peserta didik, hasil karya guru, arsip, lembar kerja dan lain lain. Pengambilan data yang berupa informasi mengenai pengetahuan, sikap, bakat dan lainnya dapat dilakukan dengan tes atau pengukuran bekal awal atau hasil belajar dengan berbagai prosedur asesmen (Budi Herijanto, 2011).

Instrumen pengumpulan data dikembangkan pada saat penyusunan usulan penelitian atau dikembangkan setelah usulan penelitian disetujui untuk didanai dan dilaksanakan. Keuntungannya bila instrumen dikembangkan pada saat penyusunan usulan adalah peneliti telah mempersiapkan diri lebih dini sehingga peneliti dapat lebih cepat mengimplementasikannya di lapangan. Pengukuran keberhasilan tindakan sedapat mungkin telah ditetapkan caranya sejak awal penelitian, demikian pula kriteria keberhasilan tindakannya (Budi Herijanto, 2011). Keberhasilan tindakan ini disebut sebagai indikator keberhasilan tindakan. Indikator keberhasilan tindakan biasanya ditetapkan berdasarkan suatu ukuran standar yang berlaku (Herawati Susilo dan Krisyani Laksono, 2008).

Di samping menetapkan berbagai model dan teknik pengumpulan data yang diperlukan, apapun yang dipilih, harus dikembangkan berdasarkan penjabaran variabel kedalam indikator dan indikator kedalam item, item dikelompokkan sesuai jenis instrumen (kisi-kisi) (Budi Herijanto, 2011). Disamping data tentang variabel juga diperlukan data pendukung terutama untuk proses tindakan. Selanjutnya diuraikan dengan jelas seperti melalui pengamatan partisipatif, pembuatan jurnal harian, observasi aktivitas di kelas (termasuk berbagai kemungkinan format dan alat bantu rekam yang akan digunakan) penggambaran interaksi dalam kelas (analisis sosiometrik), pengukuran hasil belajar dengan berbagai prosedur asesmen dan sebagainya. Selanjutnya dalam prosedur pengumpulan data PTK ini tidak boleh dilupakan bahwa sebagai pelaku PTK, para guru juga harus aktif sebagai pengumpul data, bukan semata - mata sebagai sumber data (Muhammad Daffa, 2008).

Akhirnya semua teknologi pengumpulan data yang digunakan harus mendapat penilaian kelaikan yang cermat dalam konteks PTK yang khas itu. Sebab meskipun mungkin saja memang menjanjikan mutu rekaman yang jauh lebih baik, penggunaan teknologi perekaman data yang canggih dapat saja terganjal keras pada tahap tayang ulang dalam rangka analisis dan interpretasi data (Heni Susilowati, tth.).

Validasi diperlukan agar diperoleh data yang valid. Validitas yang digunakan perlu sesuai dengan data yang akan dikumpulkan. Untuk data kuantitatif 
(berbentuk angka) umumnya yang divalidasi instrumennya. Validitas yang digunakan, validitas teoretik maupun validitas empirik. Untuk itu diperlukan kisikisi agar terpenuhinya validitas teoretik. Data kualitatif (misalnya observasi, wawancara), dapat divalidasi melalui triangulasi: triangulasi sumber, data berasal dari beberapa sumber, atau triangulasi metode, data berasal dari beberapa metode (Budi Herijanto, 2011).

\section{Indikator Kinerja}

Pada bagaian Indikator kinerja ini tolak ukur keberhasilan tindakan perbaikan ditetapkan secara eksplisit sehingga memudahkan verifikasinya untuk tindak perbaikan melalui PTK.

\section{Analisis/Interpretasi Data}

Metode analisis data, disebutkan apa yang dilakukan oleh peneliti terhadap data yang terkumpul. Jadi pekerjaan analisis data dalam PTK adalah bergerak dari penulisan deskripsi kasar catatan observasi, wawancara dan dokumentasi, misalnya kegiatan peserta didik selama pembelajaran di kelas, sampai pada produk penelitian. Dalam PTK data dianalisis pada saat pengumpulan data dan setelah selesai pengumpulan data yaitu dengan melakukan refleksi (Budi Herijanto, 2011).

Analisis data selama pengumpulan data membawa peneliti mondar-mandir antara berfikir tentang data yang ada dan mengembangkan strategi untuk mengumpulkan data baru yang biasanya yang lebih baik; melakukan koreksi terhadap informasi yang kurang jelas dan mengarahkan analisis yang sedang berjalan berkaitan dengan dampak pembangkitan kerja lapangan. Ada beberapa langkah yang ditempuh dalam analisis data selama pengumpulan data yaitu: lembar rangkuman kontak (contact summary sheet), pembuatan kode-kode, penkodean pola (pattern codding) dan pemberian memo (Budi Herijanto, 2011).

Pada tahap analisis data setelah pengumpulan data, peneliti banyak terlibat dalam kegiatan penyajian atau penampilan (display) dari data yang dikumpulkan dan dianalisis sebelumnya. Dalam penelitian kualitatif banyak disusun teks naratif. Display adalah format yang menyajikan informasi secara sistematik kepada pembaca. Terdapat dua macam format, yaitu diagram konteks (context chart) dan matriks. Berdasarkan hasil/display itu dilakukan interpretasi (Budi Herijanto, 2011).

Interpretasi berarti mengartikan hasil penelitian berdasarkan pemahaman yang dimiliki peneliti. Hal ini dilakukan dengan acuan teori, dibandingkan dengan pengalaman, praktik, atau penilaian dan pendapat guru. Hipotesis tindakan yang telah divalidasi dicocokkan dengan mengacu pada kriteria, norma, dan nilai yang telah diterima oleh guru dan peserta didik yang dikenai tindakan (Herawati Susilo dan Krisyani Laksono, 2008). 
Dalam PTK, perhatian lebih kepada kasus daripada sampel. Hal ini berimplikasi bahwa metode yang dipakai lebih dapat diterapkan terhadap pemahaman situasi problematik daripada atas dasar prediksi di dalam parameter (Herawati Susilo dan Krisyani Laksono, 2008). Tahap-tahap analisis data penelitian meliputi: (a). validasi hipotesis dengan menggunakan teknik yang sesuai (saturasi, triangulasi, atau jika memang perlu uji statistik); (b). interpretasi dengan acuan teori, menumbuhkan praktik, atau pendapat guru; (c). tindakan untuk perbaikan lebih lanjut yang juga dimonitor dengan teknik penelitian kelas (Budi Herijanto, 2011).

Analisis dilakukan dengan menggunakan hasil pengumpulan informasi yang telah dilakukan dalam tahap pengumpulan data. Misalnya, dengan memutar kembali hasil rekaman proses pembelajaran dengan video tape recorder guru mengamati kegiatan mengajarnya dan membahas masalah-masalah yang menjadi perhatian penelitian bersama dengan kolaborator/ widya iswara/ dosen. Pada proses analisis dibahas apa yang diharapkan terjadi, apa yang kemudian terjadi, mengapa terjadi tidak seperti yang diharapkan, apa penyebabnya atau ternyata sudah terjadi seperti yang diharapkan, dan apakah perlu dilakukan tindak-lanjut (Herawati Susilo dan Krisyani Laksono, 2008).

Validasi hipotesis adalah diterima atau ditolaknya suatu hipotesis. Jika di dalam desain PTK diajukan hipotesis tindakan yang merupakan keyakinan terhadap tindakan yang akan dilakukan, maka perlu dilakukan validasi. Validasi ini dimaksudkan untuk menguji atau memberikan bukti secara empirik apakah pernyataan keyakinan yang dirumuskan dalam bentuk hipotesis tindakan itu benar. Validasi hipotesis tindakan dengan menggunakan tehnik yang sesuai yaitu: saturasi, triangulasi dan jika perlu dengan uji statistik tetapi bukan generalisasi atas hasil PTK. Saturasi, apakah tidak ditemukan lagi data tambahan. Triangulasi, mempertentangkan persepsi seseorang pelaku dalam situasi tertentu dengan aktor-aktor lain dalam situasi itu, jadi data atau informasi yang telah diperoleh divalidasi dengan melakukan cek, recek, dan cek silang dengan pihak terkait untuk memperoleh kesimpulan yang objektif (Herawati Susilo dan Krisyani Laksono, 2008).

Analisis data yang akan digunakan sesuai dengan metode dan jenis data yang dikumpulkan. Pada PTK, data yang dikumpulkan dapat berbentuk kuantitatif maupun kualitatif. Pada PTK tidak harus menggunakan uji statistik, tetapi bisa saja cukup dengan deskriptif. Data kuantitatif menggunakan analisis diskriptif komparatif yaitu membandingkan misalnya nilai tes kondisi awal, nilai tes setelah siklus 1 dan nilai tes setelah siklus 2. Data kualitatif hasil pengamatan maupun wawancara menggunakan analisis diskriptif kualitatif berdasarkan hasil observasi dan refleksi dari tiap-tiap siklus (Budi Herijanto, 2011). 


\section{BAB IV HASIL PENELITIAN DAN PEMBAHASAN}

Bab IV Hasil Penelitian dan Pembahasan ini sesuai judulnya, memaparkan uraian pelaksanaan masing-masing siklus dengan data lengkap, mulai dari perencanaan, pelaksanaan, pengamatan dan refleksi yang berisi penjelasan tentang aspek keberhasilan dan kelemahan yang terjadi. Kemudian perlu ditonjolkan hal yang mendasar yaitu hasil penelitian yang sesuai dengan tujuan yang tercermin dari perubahan (kemajuan) pada diri peserta didik, lingkungan, guru sendiri, motivasi dan aktivitas belajar, situasi kelas, hasil belajar dan lain sebagainya. Kemukakan grafik dan/ tabel secara optimal, hasil analisis data yang menunjukkan perubahan yang terjadi disertai pembahasan secara sistematik dan jelas.

\section{PelaksanaanTindakan}

Pada bagian ini sistematika sajiannya dapat dibuat sebagai berikut: Kondisi Awal; Siklus I; Siklus II; Siklus III (jika ada) dan Pembahasan antar siklus serta pembahasan hasil penelitian. Kondisi awal deskripsikan fakta dari permasalahan atau kondisi variabel yang ada sebelum dilakukan penelitian, Misalnya: nilai tes rata-rata yang dicapai, aspek ketrampilan sosial yang ada, tingkat keberanian bertanya peserta didik, miskonsepsi, dan sejenisnya (Budi Herijanto, 2011).

Siklus I, untuk masing-masing siklus dapat disajikan urutan sebagai berikut:

a. Rencana tindakan (deskripsikan skenario pembelajaran),

b. Pelaksanaan tindakan (deskripsi hasil observasi proses pelaksanaan pembelajaran secara rinci dari awal sampai akhir setiap pertemuan) tiap tatap muka/ pertemuan yang diikuti refleksi hasil pengamatan guna perbaikan tatap muka/ pertemuan dan atau siklus berikutnya;

c. Hasil tindakan (sajikan/deskripsikan hasil analisis data dari observasi proses, hasil test, dan angket)

d. Hasil belajar peserta didik aspek kognitif

e. Hasil belajar peserta didik apek ketrampilan sosial (keberanian peserta didik dalam bertanya, berpendapat dan berargumentasi)

f. Efektifitas cara pembelajaran menurut peserta didik, dan seterusnya

g. Refleksi (deskripsikan hasil analisis tindakan dan bandingkan dengan indikator kinerja yang telah ditetapkan). Deskripsi ini merupakan sajian analisis kritis terhadap indikator kinerja versus hasil tindakan serta pengembangan konsep teoritis dan rencana tindak lanjut yang diperlukan. Siklus II (seperti siklus I) kemudian dilanjutkan pembahasan antar siklus.

Pelaksanaan siklus (rencana tindakan) di dalam kelas diuraikan penerapan rencana tindakan yang telah disusun dengan variasi tertentu sesuai dengan kondisi kelas. Selama pelaksanaan tindakan (sesuai RPP) dalam siklus dilakukan pula pengamatan setiap tatap muka dan dilanjutkan dengan refleksi guna perbaikan pada tatap muka atau siklus berikutnya. Baik pelaksanaan tindakan, pengamatan maupun 
refleksi dapat dilakukan secara beiringan, bahkan bersamaan. Semua hal yang berkaitan dengan hal diatas perlu didokumentasi dan dikumpulkan dengan sebaikbaiknya (Budi Herijanto, 2011).

Refleksi adalah mengingat dan merenungkan kembali suatu tindakan persis seperti yang telah dicatat dalam observasi. Lewat refleksi peneliti berusaha (1) memahami proses, masalah, persoalan, dan kendala yang nyata dalam tindakan strategik, dengan mempertimbangkan ragam perspektif yang mungkin ada dalam situasi pembelejaran kelas, dan (2) memahami persoalan pembelajaran dan keadaan kelas di mana pembelajan dilaksanakan (Budi Herijanto, 2011). Dalam melakukan refleksi, peneliti sebaiknya juga berdiskusi dengan teman guru sejawatnya untuk menghasilkan rekonstruksi makna situasi pembelajaran kelas dan memberikan dasar perbaikan rencana tindakan atau siklus berikutnya.

Refleksi memiliki aspek evaluatif; dalam melakukan refleksi, peneliti hendaknya menimbang-nimbang pengalaman menyelenggarakan pembelajaran di kelas, untuk menilai apakah pengaruh (persoalan yang timbul) memang diinginkan, dan memberikan saran-saran tentang cara-cara untuk meneruskan pekerjaan. Tetapi dalam pengertian bahwa refleksi itu deskriptif, peneliti perlu meninjau ulang, mengembangkan gambaran agar lebih hidup (a) tentang proses pembelajaran kelas, (b) tentang kendala yang dihadapi dalam melakukan tindakan di kelas, dan, yang lebih penting lagi, (c) tentang apa yang mungkin dilakukan untuk para peserta didik agar mencapai tujuan perbaikan pembelajaran (Budi Herijanto, 2011).

PTK merupakan proses dinamis, dengan empat momen dalam spiral perencanaan, tindakan, observasi, dan refleksi. Dalam praktik, proses PTK mulai dengan ide umum bahwa peneliti menginginkan perubahan atau perbaikan pembelajaran di kelasnya. Inilah keputusan tentang letak di mana dampak tindakan itu mungkin diperoleh. Setelah memutuskan medannya dan melakukan peninjauan awal, penelti (bersama kolaborator sebagai peneliti tindakan) memutuskan rencana umum tindakan. Dengan menjabarkan rencana umum ke dalam langkah-langkah yang dapat dilakukan, peneliti memasuki langkah pertama, yakni perubahan dalam strategi yang ditujukan bukan saja untuk mencapai perbaikan, tetapi juga pemahaman lebih baik tentang apa yang mungkin dicapai kemudian. Sebelum mengambil langkah pertama, peneliti harus lebih berhati-hati dan merencanakan cara untuk memantau pengaruh langkah tindakan pertama, dan apa yang mulai dilihat dari strategi dalam praktik. Jika mungkin mempertahankan pencarian fakta dengan memantau tindakannya, langkah pertama diambil. Pada waktu langkah itu dilaksanakan, data baru mulai masuk, dan keadaan, tindakan, serta pengaruhnya dapat dideskripsikan dan dievaluasi. Tahap evaluasi ini menjadi peninjauan yang segar yang dapat dipakai dalam menyiapkan cara untuk perencanaan baru (Budi Herijanto, 2011). 


\section{Hasil Analisis Data}

Menganalisis data yang telah dikumpulkan baik data tahap perencanaan, pelaksanaan tindakan, pengamatan, maupun refleksi harus disesuaikan dengan rumusan masalah yang telah ditetapkan. Hasil analisis data ini dipaparkan sebagai hasil PTK. Hal-hal yang perlu diperhatikan pada proses analisis hasil PTK: data PTK pada dasarnya dikumpulkan oleh guru yang berperan sebagai peneliti dan pengajar, dan jika perlu dapat dibantu oleh teman sejawat. Data tersebut lebih banyak bersifat kualitatif, meski ada juga yang berupa data kuantitatif (Budi Herijanto, 2011). Analisis data adalah upaya yang dilakukan oleh guru yang berperan sebagai peneliti untuk merangkum secara akurat data yang telah dikumpulkan dalam bentuk yang dapat dipercaya dan benar. Sehubungan dengan itu, maka analisis data dilakukan dengan cara memilih, memilah, mengelompokkan, data yang ada, merangkumnya, kemudian menyajikan dalam bentuk yang mudah dibaca atau dipahami. Penyajian hasil analisis data kualitatif dapat dibuat dalam bentuk uraian singkat, bagan alur, atau tabel sesuai dengan hakikat data yang dianalisis (Parjan, 2008).

Data kuantitatif dianalisis dengan statistik deskriptif untuk menemukan persentase, dan nilai rata-rata. Penyajian hasil analisis dapat dilakukan dengan membuat tabel distribusi atau grafik (Budi Herijanto, 2011). Analisis Interpretasi data adalah upaya peneliti untuk menemukan makna dari data yang dikumpulkan untuk menjawab pertanyaan penelitian. Interpretasi ini pada gilirannya akan menjadi temuan penelitian. Analisis yang akurat dan cara penyajian yang tepat akan memungkinkan tafsiran/interpretasi hasil penelitian yang akurat dan valid itu. Oleh karena itu, guru harus sangat berhati-hati dalam melakukan analisis. Kekurangakuratan dapat diminimalkan dengan melakukan "cross check” dengan sumber data atau dengan data lain yang sejenis. Agar mampu melakukan analisis data, guru harus banyak melakukan latihan dan bekerja dalam kelompok (Parjan, 2008).

Sajikan hasil PTK sewajarnya secara sistematis. Jika data terlalu banyak, adakalanya perlu selektif dalam menyajikannya. Dengan pertimbangan yang masak, rancanglah tabel, grafik, gambar atau alat penolong lain untuk memperjelas dan mempersingkat uraian yang harus diberikan. Jangan memberikan informasi berulang, misalnya dalam bentuk tabel dan gambar. Tabel dan/ gambar perlu disebut dalam teks dan letaknya tidak berjauhan dari teks yang bersangkutan. Hindari pengulangan informasi yang sudah ada dalam ilustrasi secara panjang lebar. Tafsirkan hasil yang diperoleh dengan memperhatikan dan menyesuaikannya dengan masalah dalam pendahuluan atau hipotesis yang diungkapkan dalam kajian pustaka (Budi Herijanto, 2011). 


\section{Pembahasan}

Setelah penulisan hasil penelitian, perlu dibuat pembahasan berdasarkan kajian teori serta hasil-hasil penelitian yang relevan sebagai pijakkan membuat kesimpulan dan rumusan saran; Sewaktu mengumpulkan data, mengolahnya, dan menyusunnya dalam tabel. Dengan begitu kita telah memiliki sejumlah gagasan yang siap dikembangkan dalam Pembahasan (Budi Herijanto, 2011). Pengembangan gagasan ini disebut argumen. Kita harus membandingkan hasil dengan hasil-hasil penelitian terdahulu, kemudian membuat pertimbangan teoretisnya. Dengan demikian, Pembahasan merupakan kumpulan argumen mengenai relevansi, manfaat, dan kemungkinan atau keterbatasan penelitian. Pembahasan merupakan bagian tempat seseorang paling bebas berekspresi. Pendapat orang yang sudah diringkas dalam Pendahuluan atau Tinjauan Pustaka tidak perlu diulang lagi, tetapi diacu saja seperlunya. Bentangkan arti temuan serta jelaskan bagaimana simpulan baru itu memperluas cakrawala ilmu dan teknologi (sesuai janji pada manfaat teoritis pada bab 1). Bila perlu berikan implikasi penerapan temuan baru tadi dan tunjukkan segi-segi lain yang perlu diteliti lebih lanjut (menjadi embrio saran bab 5 nanti). Akhiri pembahasan secara positif, tegas, dan kuat (Budi Herijanto, 2011).

Unsur-unsur yang dapat dituliskan dalam berargumen dan menyampaikan implikasi dari temuan, yaitu:

1) Nyatakan situasi yang ditemukan dalam penelitian: bisa memuaskan atau tidak memuaskan. Misalnya: guru kelas SD belum memenuhi standar minimal kompetensi untuk mengajarkan sains.

2) Nyatakan kemungkinan penyebab situasi itu. Jika ada situasi, mestinya ada penyebab, dan mestinya ada hubungan logis antara situasi dan penyebab, bila tidak, yang dianggap penyebab bukanlah penyebab yang sesungguhnya. Dalam contoh di atas, yang dianggap logis kurangnya kompetensi untuk menangani mata pelajaran sains ialah kurang cermatnya rekruitmen dalam menyeleksi calon guru, atau tidak cukupnya pelamar yang berkualifikasi untuk menduduki posisi guru kelas SD atau SMP.

3) Nyatakan efek yang mungkin timbul dari situasi itu. Hampir pasti, ada pula efek yang ditimbulkan dari situasi tersebut dan mestinya ada hubungan logis antara situasi dan efek yang mungkin. Efek logis dari kurangnya guru berkompetensi pada pengajaran sains ialah pengajaran akan kurang efektif dan ini dapat merugikan peserta didik dan mutu SD atau SMP yang bersangkutan.

4) Nyatakan tindakan untuk mengatasi situasi yang kurang memuaskan atau untuk meningkatkan situasi yang sudah baik. Wajar saja untuk mengambil tindakan guna mengatasi situasi yang kurang memuaskan. Namun, situasi yang sudah baik pun perlu terus dipertahankan atau bahkan ditingkatkan. 
Langkah logis untuk mengatasi keadaan guru yang tidak berkompeten ialah dengan mensyaratkan peningkatan kualitas melalui pendidikan dan latihan dalam bidang sains, menghadiri seminar, mengikuti pelatihan, membaca lebih banyak publikasi sains.

5) Nyatakan badan atau bidang terkait yang terpengaruhi. Dalam contoh yang diambil ini, pengajaran sains di SD tertentu yang terpengaruhi, bagaimana dengan guru SD dalam satu Gugus/Kecamatan bahkan Kabupaten atau Propinsi?. Anda dapat melanjutkan pembahasan tentang implikasi temuan pada pengajaran sains di SD. Walau perlu disadari bahwa implikasi ini barangkali tidak berlaku untuk keadaan pendidikan secara keseluruhan dalam satu wilayah tertentu (Budi Herijanto, 2011).

\section{BAB V SIMPULAN DAN SARAN}

Menyimpulkan adalah mengikhtisarkan atau memberi pendapat berdasarkan apa-apa yang diuraikan sebelumnya. Sejalan dengan itu, kesimpulan atau simpulan adalah kesudahan pendapat atau pendapat terakhir yang dibuat berdasarkan uraian sebelumnya (Budi Herijanto, 2011). Dalam kaitan dengan PTK, simpulan harus disusun secara singkat, padat, dan jelas; sesuai dengan uraian, dan mengacu kepada pertanyaan penelitian/ tujuan perbaikan. Di samping itu, simpulan harus disusun secara sistematis sesuai dengan urutan pertanyaan penelitian/tujuan perbaikan (Parjan, 2008).

Penyusunan simpulan seyogianya dilakukan melalui langkah-langkah: 1) memeriksa dan memahami pertanyaan penelitian/tujuan perbaikan, 2) mencermati, menganalisis, dan mensintesis deskripsi temuan, 3) menulis kesimpulan untuk setiap pertanyaan penelitian/ tujuan perbaikan, 4) mengurutkan setiap butir kesimpulan sesuai dengan urutan pertanyaan penelitian/tujuan perbaikan, serta 5) memeriksa kesesuaian antara pertanyaan penelitian/ tujuan perbaikan dengan deskripsi temuan, dan kesimpulan. Dalam menarik kesimpulan, bersikaplah kritis, dan lihat apakah kesimpulannya dapat ditafsirkan secara lain. Cukup luaskah perampatan yang digariskan dengan melibatkan kesimpulan, hasil, pendapat, dan teori yang ada (Parjan, 2008; Budi Herijanto, 2011).

Simpulan menjelaskan butir-butir temuan (hasil penelitian dan pembahasan) yang disajikan secara singkat dan jelas. Kesimpulan adalah inferens, deduksi, abstraksi, implikasi, interpretasi, pernyataan umum, dan atau perampatan berdasarkan temuan penelitian. Kesimpulan adalah turunan logis dan sahih dari hasil penelitian. Sebaiknya kesimpulan tidak mengandung angka, sebab angkaangka biasanya membatasi efek atau dampak cakupan perampatan. Jangan menyimpulkan apapun dari hal-hal yang tidak diteliti (Budi Herijanto, 2011). 
Simpulan harus menjawab permasalahan penelitian. Penelitian dapat dikatakan tidak berarti bilamana permasalahan penelitian tidak terjawab dengan baik. Kesimpulan harus dibuat berdasarkan fakta, bukan yang tersirat daripadanya. Kesimpulan harus dirumuskan dengan ringkas dan cermat, tetapi mengandung semua informasi hasil penelitian sebagaimana yang menjadi permasalahan penelitian. Pernyataan kesimpulan harus tegas, jangan ada keraguan dalam hal kesahihan dan keterandalan. Penggunaan kata seperti mungkin, barangkali, kiranya, dan tampaknya sedapat mungkin dihindari. Simpulan hanya mengacu pada subyek, tempat, atau kondisi tertentu sesuai cakupan penelitian. Simpulan tidak mengandung pengulangan pernyataan yang sudah dikemukakan sebelumnya. Informasi yang sama dapat dikemukakan dengan kalimat atau ungkapan yang berbeda (Budi Herijanto, 2011).

Saran dimaknai sebagai: pendapat (usul, anjuran, cita-cita) yang dikemukakan untuk dipertimbangkan. Dalam kaitan dengan PTK, saran merupakan pemikiran yang diajukan oleh peneliti untuk menindaklanjuti hasil penelitiannya. Saran tindak lanjut hasil PTK harus memenuhi rambu-rambu: 1) bersumber atau sesuai dengan kesimpulan, 2) bersifat kongkret, operasional, dan penting, sehingga menarik untuk dilaksanakan oleh guru, dan fihak lain (3) jelas sasarannya, apakah ditujukan kepada guru atau sekolah, atau barangkali instansi lain, serta (4) dapat meliputi halhal yang berkaitan dengan metodologi penelitian (Parjan, 2008). Mengingat saran merupakan himbauan kepada fihak-fihak terkait maupun peneliti berikutnya maka harus berdasarkan pada hasil temuan. Saran sebaiknya selaras dengan topik dan manfaat penelitian. Saran yang dikemukakan mestinya berasal dari hal-hal yang berkaitan dengan pelaksnaaan atau hasil penelitian. Jangan ungkapkan saran ".... agar penelitian ini dilanjutkan", mengapa? (Budi Herijanto, 2011).

Pembuatan saran dapat dilakukan melalui langkah-langkah: 1) mencermati kesimpulan hasil PTK, 2) mengkaji aspek-aspek dari kesimpulan tersebut yang perlu ditindaklanjuti, baik oleh guru peneliti, guru lain, maupun sekolah, 3) menetapkan kepada siapa saran tersebut akan ditujukan, serta 4) menulis saran (Budi Herijanto, 2011).

Saran sebaiknya memiliki ciri seperti berikut ini. Ditujukan untuk mengatasi atau membantu menyelesaikan masalah yang diselidiki. Saran harus berkait dengan hal-hal yang dibahas. Saran untuk hal yang tidak dibahas tidaklah relevan. Praktek atau sistem yang baik dapat disarankan untuk digunakan, atau bahkan disarankan untuk diperbaiki. Saran harus dapat dikerjakan dan praktis. Tidak ada gunanya menyarankan hal-hal yang mustahil. Saran harus logis dan sahih. Saran dapat ditujukan kepada orang, lembaga, atau satuan yang berwenang untuk melaksanakannya. Penelitian lanjutan dapat disarankan untuk maksud verifikasi, penguatan, atau bahkan melawan temuan penelitian (Budi Herijanto, 2011). 


\section{BAGIAN AKHIR}

Bagian akhir dari format laporan penelitian terdiri dari Daftar Pustaka dan lampiran-lampiran. Ada dua hal yang berkaitan dengan Daftar Pustaka/acuan, yaitu: 1) Petunjuk pengacuan pada teks, dan 2) Penyusunan Daftar Pustaka. Tuliskanlah semua bacaan atau referensi yang dimuat dalam bagian pokok laporan ini. Teknik yang dipergunakan dalam menulis referensi, kita bisa menggunakan metoda penulisan yang telah diseragamkan oleh American Psychological Association (APA). Jurnal Scholaria menganutnya.

Lampiran memuat hal-hal atau informasi yang mendukung bab-bab sebelumnya yang terdapat pada bagian pokok laporan penelitian, misalnya: RPP, instrumen pengumpulan data (tes, lembar observasi, questionaire, data dokumen, wawancara dan seterusnya) baik sebelum maupun setelah uji coba, informasi yang terkait dengan hasil baik data mentah maupun olahan komputer, diskripsi, hasil uji validitas dan reliabilitas dan sebagainya (Budi Herijanto, 2011).

\section{PENUTUP}

Laporan PTK merupakan pernyataan formal tentang hasil penelitian, ditulis secara sistematis berdasarkan penelitian tindakan kelas yang dilakukan oleh guru di kelasnya sendiri. Tujuan menulis laporan secara sederhana adalah untuk mencatat, memberitahukan, dan merekomendasikan hasil penelitian. Laporan PTK ditulis karena merupakan dokumen yang dapat dijadikan acuan, serta dapat diketahui oleh umum, terutama oleh para guru yang barangkali mengalami masalah yang sama dengan yang dilaporkan.

Sistematika laporan hasil PTK terdiri dari 3 bagian yaitu: awal, pokok, dan akhir yang saling terkait. Bagian awal terdiri dari: halaman judul, kata pengantar, abstrak, daftar isi, daftar tabel, daftar gambar dan daftar lampiran. Bagian Pokok Laporan terdiri dari 5 bab, yaitu Bab I Pendahuluan, Bab II Kajian Pustaka, Bab III Metode Penelitian Tindakan Kelas, Bab IV Pelaksanaan dan Hasil Penelitian Tindakan Kelas serta Pembahasan, Bab V Penutup. Bagian akhir dari format laporan penelitian terdiri dari daftar pustaka dan lampiran-lampiran.

\section{DAFTAR PUSTAKA}

Aqib. Z. 2008. Penelitian Tindakan Kelas. Bandung: Tyrama Widya.

Arikunto. S., Suhardjono., \& Supardi. 2008. Penelitian Tindakan Kelas. Jakarta: Bumi Aksara.

Aunurrahman, dkk. 2009. Penelitian Pendidikan SD. Jakarta: Dirjen PT Depdiknas

Bambang Yulianto. Ed. 2013. Modul PLPG Bahasa Indonesia. http://repository.ung.ac.id/get/kms/2896/ 
Budi Herijanto. 2011. Teknik Penulisan Laporan PTK. http://budipesona.blogspot.co.id/2011/06/

Hatimah, I., Susilana, R., dan Nuraedi, 2008. Penelitian Pendidikan, Jakarta: Depdiknas Dirjen Dikti

Heni Susilowati. Tth. Pengertian dan Karakteristik Penelitian Tindakan Kelas. https://www.academia.edu/6836930/Ptk_sriyani

Herawati Susilo dan Krisyani Laksono. 2008. Penelitian Tindakan Kelas-Bentuk dan Skenario Tindakan, Serta Pengembangan Instrumen untuk Mengukur Keberhasilan Tindakan. https://ptkguru.wordpress.com/2008/05/11/ penelitiantindakan-kelas\%E2\%80\%94

I Wayan Santyasa, 2007. Metodologi Penelitian Tindakan Kelas. Workshop tentang Penelitian Tindakan Kelas (PTK) bagi Para Guru SMP 2 dan 5 Nusa Penida Klungkung, pada tanggal 30 Nopember s.d 1 Desember 2007 di Nusa Penida

Muhammad Daffa. 2008. Penelitian Tindakan Kelas Meningkatkan Kualitas KBM. https://ardansirodjuddin.wordpress.com/2008/05/26/

Muslich, M. 2009. Melaksanakan PTK itu Mudah. Jakarta: Bumi Aksara.

Parjan. 2008. Analisis Hasil Penelitian Tindakan Kelas (PTK), Tindak Lanjut dan Penulisan Laporan. http://parjan-binkusnadi.blogspot.co.id/ 2012_03_01_ archive.html

Slameto, 2008. Proposal, Pelaksanaan Dan Evaluasi Keberhasilan PTK. Seminar Nasional IKIP PGRI Semarang 19 Juni 2008

Slameto, 2010. Teknis Penyusunan Laporan Hasil PTKhttp://sumoslamet. blogspot.com/2010/07/

Slameto, 2011. Penyusunan Proposal dan Hasil Penelitian Tindakan Kelas. Salatiga: Widya Sari Press

Wahidmurni. 2008. Cara Mudah Menulis Proposal dan Laporan Penelitian Lapangan. Malang: IKIP Malang. 